\title{
Eco-friendly management of pulse beetle (Callosobruchus chinensis L.) in stored chickpea (Cicer arietinum) under laboratory conditions
}

\section{ARUN KUMAR SINGH AND R.K. PANDEY}

\author{
Article Chronicle : \\ Received: \\ 30.12.2015; \\ Revised : \\ 14.04.2016; \\ Accepted : \\ 25.04.2016
}

Key Words : Callosobruchus chinensis, ecofriendly, Cicer arietinum
ABSTRACT : An experiment was conducted to know the effect of Eco-friendly management of pulse beetle in chickpea (Vaibhav) storage at ambient conditions. The nine eco-friendly protectants, Dhatura seed powder, Tobacco leaf powder, Bhaitt leaf powder, Leman leaf powder, Ginger rhizome powder, Bitter gourd seed powder, Asafoetida latex, Gunghchi seed powder, and Alocasia leaves powder will be used in the experiment. The different observations viz., per cent moisture contents, per cent infestation and per cent germination were evaluated at 3 to 6 months of storage. The results revealed that all Protectants were statistically significantly superior to untreated check. Per cent infestation being main parameter of protectants, the maximum moisture content, germination per cent and minimum infestation in asafoetida latex and maximum infestation, minimum germination in ginger rhizome powder and minimum moisture contents in alocasia leaf powder after three months storage. Maximum germination, minimum infestation in asafoetida latex and maximum moisture content in gunghchi seed powder, minimum in tobacco leaf powder and maximum infestation, minimum germination in alocasia leaf powder after six months storage period. Eco-friendly protectants can be used as sustainable, safer human and environment, alternative to Protectants for long term storage of pulses.

HOW TO CITE THIS ARTICLE : Singh, Arun Kumar and Pandey, R.K. (2016). Eco-friendly management of pulse beetle (Callosobruchus chinensis L.) in stored chickpea (Cicer arietinum) under laboratory conditions. Asian J. Environ. Sci.,11(1): 13-18, DOI: 10.15740/HAS/AJES/11.1/13-18. 